\title{
Structurally conserved C-RFa revealed prolactin releasing activity in vitro and gene expression changes in pituitary of seasonally acclimatized carp
}

\author{
Alex Romero ${ }^{1}$, Rodrigo Montefusco-Siegmund ${ }^{2}$, Guillermo Valenzuela², Gudrun Kausel ${ }^{2}$, Marc Muller ${ }^{3}$, Sebastian \\ Brauchi $^{4}$, And Jaime Figueroa ${ }^{2}$
}

${ }^{1}$ Instituto de Patología Animal, Facultad de Ciencias Veterinarias, Universidad Austral de Chile, Casilla 567, Valdivia, Chile
2 Instituto de Bioquímica, Facultad de Ciencias, Universidad Austral de Chile, Casilla 567, Valdivia, Chile
3 Laboratoire de Biologie Moleculaire et de Genie Genetique, Universite de Liege, Institut de Chimie B6, B-4000 Sart-Tilman, Belgium
${ }^{4}$ Instituto de Fisiología, Facultad de Medicina, Universidad Austral de Chile, Casilla 567, Valdivia, Chile

\begin{abstract}
Here we show the cloning and characterization of a novel homolog of prepro C-RFa cDNA from Cyprinus carpio. The deduced preprohormone precursor of 115 amino acids leads to a mature bioactive peptide of 20 amino acids with identical sequence to other teleost C-RFa. Modeling of the mature C-RFa peptide highlighted significant similarity to homologous human PrRP20, specifically the conserved amphipathic system defined by the C-terminal alpha-helix. Clearly, the synthetic C-RFa peptide stimulated prolactin release from primary cultured fish pituitary cells. For the first time, significant variation was shown in C-RFa mRNA and protein levels in the hypothalamus and pituitary between summer- and winter-acclimatized carp. Furthermore, C-RFa protein distribution in carp central nervous tissue was visualized by immunodetection in fibers and cells in hypothalamus, olfactory tract, cerebellum and pituitary stalk. In conclusion, we demonstrated the structure conservation of C-RFa in teleosts and mammals and immunopositive cells and fibers for C-RFa in brain areas. Finally, the increase of C-RFa expression suggests the participation of this hypothalamic factor in the mechanism of modulation in PRL expression in carp.
\end{abstract}

Key words: C-RFa peptide, prolactin releasing activity, Cyprinus carpio.

\section{INTRODUCTION}

Prolactin (PRL) has over 300 separate biological activities in mammals, while in fish it plays important roles in freshwater osmoregulation (Manzon 2002), immunomodulation (Yada and Azuma 2002; Yada et al. 2002), reproduction (Weber and Grau 1999) and seasonal acclimatization (Figueroa et al. 1994). PRL secretion is inhibited by somatostatin in the tilapia pituitary (Grau et al. 1982; Helms et al. 1991) and stimulated by a gonadotropin-releasing hormone (GnRH) (Weber et al. 1997) and TRH (Barry and Grau 1986).

A specific prolactin-releasing peptide was isolated from bovine hypothalamus (PrRP) (Hinuma et al. 1998). PrRP presents two amidated isoforms, PrRP20 and PrRP31. The two bioactive peptides display similar abilities to specifically stimulate prolactin secretion from the anterior pituitary gland in vivo and in vitro (Hinuma et al. 1998). Their specific receptor, GPR10, belongs to the G-coupled protein receptor superfamily, GPCR (Marchese et al. 1995; Welch et al. 1995), which is a member of the $\beta$ group in the rhodopsin family (Fredriksson et al. 2003).

In fish, an analogous peptide to PrRP has been isolated from brain of the Japanese crucian carp (Carassius auratus langsdorfii) and was designated Carassius RFamide (C-RFa) (Fujimoto et al. 1998). A similar C-RFa peptide was identified in chum salmon (Oncorhynchus keta), Atlantic salmon (salmo salar), tilapia (Oreochromis mossambicus) and silver sea bream (Sparus sarba) (Kwong and Woo 2008; Montefusco-Siegmund et al. 2006; Moriyama et al. 2002; Seale et al. 2002). The cDNA encoding the preprohormones encodes a putative bioactive peptide of 20 amino acids, identical in all the teleost species studied and 65\% similar to homologous human PrRP20 (h-PrRP). Immunoreactive fibers for C-RFa have been described close to the PRL cells of rostal pars distalis RPD in rainbow trout pituitary (Moriyama et al. 2002) and the peptide was able to stimulate specifically PRL release in vitro in tilapia and in vivo and in vitro in rainbow trout, suggesting that C-RFa is a specific prolactin releasing factor in teleosts (Moriyama et al. 2002; Seale et al. 2002). The specific receptor of the C-RFa was cloned from tilapia and its expression was detected in the pituitary gland of this teleost (Watanabe and Kaneko 2010).

Here we present preproC-RFa deduced from Cyprinus carpio cDNA, the structural model of the mature peptide, its distribution in brain and pituitary gland, modulation of its expression during seasonal acclimatization and its PRL releasing activity from primary culture lactotrophs in vitro.

\section{MATERIALS AND METHODS}

Animals and tissue preparation

Adult male carp (Cyprinus carpio) weighing about 1000 - 1500g were caught during winter and summer and maintained in a fixed $3 \times 4 \mathrm{~m}$ cage submerged $2 \mathrm{~m}$ in an affluent of the same river. The water temperatures in winter and in summer were 8 $-10^{\circ} \mathrm{C}$ and $18-20^{\circ} \mathrm{C}$, respectively. Pituitary glands from winterand summer-acclimatized carp were dissected and either fixed immediately for inmunocytochemical analyses or frozen in liquid nitrogen and stored at $-80^{\circ} \mathrm{C}$ for RNA extraction. 


\section{Cloning of carp C-RFa cDNA}

Total RNA was extracted from $200 \mathrm{mg}$ of carp hypothalamus according to standard procedures (Sambrook et al. 1989). First-strand cDNA was obtained from total RNA using a SuperScript II Reverse Transcriptase (Invitrogen). The coding cDNA sequence was cloned with the following strategy. First, a partial cDNA sequence from carp C-RFa was amplified with degenerate primers (MontefuscoSiegmund et al., 2006). Based on this nucleotide sequence from carp, two gene-specific primers were used for cloning the 5'- and 3'regions carp C-RFa as follows: cyppepfor 5`-GGATCTGGCTGCTGTCGTGTGTG-3` and cyppeprev 5`-CCACGCAGTTGCGGAGTTTGACC-3`. The 5`-region of carp C-RFa cDNA was amplified using a heterologous primer designed from zebrafish C-RFa (Lagerstrom et al. 2005), ZfpepATG 5`-ATGCTGCTCACCGCCTTCACTC-3` and cyppeprev primer. During PCR, $2 \mu \mathrm{l}$ first strand cDNA, primers $0.8 \mu \mathrm{M}$ each, nucleotide mix $0.4 \mathrm{mM}, \mathrm{MgCl}_{2} 2 \mathrm{mM}$, $5 \mu \mathrm{l}$ 10X PCR buffer and 1.25 U Taq DNA polymerase (Roche Applied Biosystems, Foster City, CA) were subjected to 30 cycles of amplification. After initial denaturation of the DNA $94^{\circ} \mathrm{C}$ for $3 \mathrm{~min}$, each cycle consisted of $45 \mathrm{~s}$ denaturation at $94^{\circ} \mathrm{C}, 45 \mathrm{~s}$ primer annealing at $67^{\circ} \mathrm{C}$ and $1 \mathrm{~min}$ primer extension at $72^{\circ} \mathrm{C}$. The final extension was $5 \mathrm{~min}$ at $72^{\circ} \mathrm{C}$. For cloning of the $3{ }^{\circ}$ - end, cyppepfor primer and the oligo dT adapter primer (5'-AGAGTGGTAACAACTTTTTTTTTTTTTTTTTTTTTVV-3') were used for RT-PCR, using the same conditions described above. The cDNA nucleotide sequence was determined by sequencing according to the dideoxy chain termination method with a DNA sequencer.

For quantitative real-time RT-PCR experiments, amplification was performed by denaturation for $30 \mathrm{~s}$ at $94^{\circ} \mathrm{C}$, annealing for $30 \mathrm{~s}$ at $55^{\circ} \mathrm{C}$, and elongation for $30 \mathrm{~s}$ at $72^{\circ} \mathrm{C}$. The primers used were: carp $\beta$-actin derived from sequence M24113: $c \beta$-acts 5'-GGACCTGTATGCCAACACTG-3' and $c \beta$-acta 5'-GTCGGCGTGAAGTGGTAACA-3' (amplicon size in cDNA 281bp); carp C-RFa: Cyppepfor 5'-CGATAACAGAAGTCCAGAGATTG-3' and Cyppeprev 5'-GCCAGTCGGCGTCCTCCTGC-3', (amplicon size in cDNA 191bp); carp Cp: cCp-1s 5'-CGGTTATGAAGGACACTGCG-3' and cCp-2a 5'-TGGCTTGACCCGGTGCAGCAG-3' (amplicon size in cDNA $159 \mathrm{bp}$ ). Constitutive expression of C-RFa in winter and summer was determined in hypothalamus of three individual adult carp, and rendered as a ratio of target gene vs. reference gene ( $\beta$-actin) calculated with the Pfaffl method (Pfaffl 2001), according to the following equation:

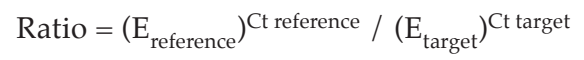

where $\mathrm{E}$ is the amplification efficiency and $\mathrm{Ct}$ is the number of PCR cycles needed for the signal to exceed a predetermined threshold value. The data obtained were expressed as mean and standard deviations (SD) and the significance of differences was determined using the student t-test.

\section{Immunohistochemistry}

Fish were anesthetized with $0.05 \%$ 2-phenoxyethanol, and brains with pituitary were fixed with Bouin's fluid at $4^{\circ} \mathrm{C}$ for 24 h. Subsequently, the tissue was dehydrated and embedded in Paraplast. Immunohistochemistry was conducted as described in (Moriyama et al. 2002). An anti-synthetic C-RFa serum was used for the assays (Wang et al. 2000).

Preparation of lactotroph primary culture of rainbow trout

Pituitary cells were dispersed in culture according to established protocols (Chang and Jobin 1994). Briefly, pituitary cells were dissociated with $0,25 \%$ trypsin type II in dispersion media (Medium 199 with Hanks' salts, 25 mM HEPES, 2.2 $\mathrm{g} / \mathrm{L}$ sodium bicarbonate, $0.3 \%$ bovine serum albumin, 100,000 $\mathrm{U} / \mathrm{L}$ penicillin, $100 \mathrm{mg} / \mathrm{L}$ streptomycin, $\mathrm{pH}$ 7.2). The cells were harvested by centrifugation $(200 \mathrm{xg}, 10 \mathrm{~min})$, and the pellet resuspended in $5 \mathrm{ml} \mathrm{Ca}^{2+}$-free medium. Cell yield and viability was determined by Trypan Blue exclusion. These cultured cells correspond mainly to lactotroph cells (Montefusco et al, 2006).

Immunodetection of in vitro PRL release mediated by $C-R F a$ : Dispersed cells of rainbow trout pituitary were diluted in Medium 199 with Hanks' salts, supplemented with $25 \mathrm{mM}$ HEPES, $2.2 \mathrm{~g} / \mathrm{L}$ sodium bicarbonate, $100.000 \mathrm{U} / \mathrm{L}$ penicillin, $100 \mathrm{mg} / \mathrm{L}$ streptomycin, $\mathrm{pH} 7.2$ and $5 \%$ horse serum, to a concentration of $2,5 \times 10^{5}$ cells per well in 12-well cell culture plates, incubated for $24 \mathrm{~h}$ at $25^{\circ} \mathrm{C}$ and then challenged for 5 min, $10 \mathrm{~min}$ and $30 \mathrm{~min}$ with synthetic C-RFa peptide, final concentration $10 \mathrm{nM}$. For PRL immunofluorescent detection in lactotroph cells, the monolayer culture was fixed with paraformaldehyde $2 \%$ and incubated over night with antitilapia prolactin mouse serum (1:500), followed by incubation with Alexa Fluor ${ }^{\circledR} 568$ goat anti-mouse for $1 \mathrm{~h}$ at room temperature and analyzed by confocal microscopy (Zeiss dual laser confocal microscope). For C-RFa detection, the previously described anti-C-RFa antibody (Montefusco et al) was used. After C-RFa incubation, medium was harvested and proteins quantified using the Bradford method (Sambrook et al., 1989). Proteins were fractionated on a $12 \%$ polyacrylamide-SDS gel, electrotransferred to nitrocellulose and PRL immunodetected with anti-tiPRL at 1:500 (Sambrook et al. 1989).

Molecular Modeling: Homology modeling was carried out for the C-RFa primary sequence (TPDINPAWYASRGIRPVGRF) using as template the coordinates for h-PrRP20 obtained previously by NMR (D'Ursi et al. 2002). Alignment for the homology modeling was performed using LIALIGN. The homology modeling was performed using Modeler 7.7 (Marti-Renom et al. 2000). WATH IF web interface was used to check the obtained structures. The models showing the lowest energy profiles were selected. Molecular modeling protocols were performed using Hyperchem 7.5 professional (Hypercube, INC.) with CHARMM 27 force field. The best model selected previously was minimized using the steepest descent protocol in vacuo in presence of counter ions. A periodic box was constructed and explicit water molecules were added. Four 20 ps annealing protocols were done (heating 300k, cooling 100k, cooling steps $1 \mathrm{k} / 0,01 \mathrm{ps})$. Each annealing was followed by 30 cycles of conjugate gradients minimization and 30 cycles of steepest descent minimization or until convergence was reached. Finally, all structures obtained were compared by superimposition over the template and RMS for backbone and lateral chains was calculated. Images were made using VMD 1.8.4 (Humphrey et al. 1996). 
RESULTS

cDNA cloning of C. carpio C-RFa

The sequence of the complete carp preproC-RFa cDNA (GenBank accession number DQ375239), contains a 348 bp open reading frame with $154 \mathrm{bp} 3$ ' untranslated region including the polyadenylation signal AATAAA at position 462-467 (Fig. 1). The derived sequence of 115 amino acid of carp preproC-RFa included typical proteolytic cleavage sites, arginine/serine and lysine/arginine, located at positions 53 and 75-76 respectively. The C-terminal amidation motif (GKR) was identified at positions $74-76$, suggesting that the putative mature carp C-RFa is identical to C-RFa in other teleost. The carp C-RFa precursor displayed high identity with crucian carp and zebrafish (95\% and $89 \%$, respectively). Interestingly, the sequence of the predicted bioactive peptide was perfectly identical in all species of teleosts (Fig. 2).

Structural conservation of teleost C-RFa respect to human PrRP: The high identity in the primary structures of bioactive C-RFa and h-PrRP20 (60\%, 12/20; and 85\% homologous residues 17/20, Fig. 3B) made C-RFa perfectly suitable for modeling procedures. A predicted 3-D structure was obtained for C-RFa using the known structure of h-PrRP20 and thermodynamically optimizing the variant structure. The main differences found between the template and the obtained model reside in the position of lateral chains at both ends of the molecule, probably due to higher flexibility of the backbone in that region. However, the obtained model for C-RFa (including all lateral chains) was almost identical to other structures that the h-PrRP20 peptide can adopt. A comparison between the obtained C-RFa molecular model and different structures of h-PrRP20 was possible since the original file of the template contains multiple RMN coordinates for the protein in solution. Both peptides share a similar C-terminal helical portion, where the polar aminoacid side chains Arg12, Arg15, and Arg19 (Fig. 3A) together with the apolar side chains of Val10, Val14, and Phe20 (not shown) define an amphipatic $\alpha$-helix. The N-terminal region of the C-RFa peptide tends to adopt a -turn structure including the conserved residues Pro2, Ile4, Pro6 Thr8 and Tyr9. Finally, the overall spatial orientation is conserved relative to the human peptide.

Immunolocalization of C-RFa in carp brain: C-RFa immunoreaction was detected in extensive brain regions. Numerous reactive fibers occurred in hypothalamus with a small number of C-RFa-positive cells and abundant fibers (Fig. 4A), close to recessus lateralis and recessus posterior (Fig. 4G). Fibers and axons were found in the pituitary stalk, specifically in herring bodies (Fig. 4B). In cerebellum, numerous cell bodies were found (Fig 4D, and amplification in E) in the nuclear layer, possibly in GABAergic Golgi type II cells since granular cells represent the majority of cells in this area (Martyniuk et al. 2007). The control using the antibody preabsorbed with synthetic C-RFa peptide did not immunoreact in hypothalamus (Fig. 4C) and cerebellum (Fig. 4F). C-RFa immunodetection is summarized in a schematic illustration of a sagittal section of carp brain (Fig. 4G).

C-RFa stimulated PRL release in pituitary primary cell culture: In trout primary culture of pituitary cells, PRL was clearly detected by inmmunofluorescence analyses in $90 \%$ of the cells (Fig. 5A), as previously described (Montefusco et al., 2006). After addition of synthetic C-RFa peptide, the PRL

$$
\begin{aligned}
& \text { ATGCTGCTCACCGCCTTCACTCAGCCGGTGACTAAGTGCCTGATTGGCTCGCGCTTGGGA } 60 \\
& \begin{array}{lllllllllllllllllllll}
\mathrm{M} & \mathrm{L} & \mathrm{L} & \mathrm{T} & \mathrm{A} & \mathrm{F} & \mathrm{T} & \mathrm{Q} & \mathrm{P} & \mathrm{V} & \mathrm{T} & \mathrm{K} & \mathrm{C} & \mathrm{L} & \mathrm{I} & \mathrm{G} & \mathrm{S} & \mathrm{R} & \mathrm{L} & \mathrm{G} & 20
\end{array} \\
& \text { ACGGTCGCGTTCCTGCTGCTGCTAATTCTGTCCGCCACTGAGACACACGGTACCACAGTC } 120 \\
& \begin{array}{lllllllllllllllllllll}
\text { T } & V & A & F & \text { L } & \text { L } & \text { L } & \text { L } & \text { I } & \text { L } & \text { S } & \text { A } & \text { T } & \text { E } & \text { T } & \text { H } & \text { G } & \text { T } & \text { T } & \text { V } & 40
\end{array} \\
& \text { GAGCACGACCTACATATCGTCCACAACGTCGATAACAGAAGTCCAGAGATTGACCCGTTC } 180 \\
& \begin{array}{lllllllllllllllllllll}
\mathrm{E} & \mathrm{H} & \mathrm{D} & \mathrm{L} & \mathrm{H} & \mathrm{I} & \mathrm{V} & \mathrm{H} & \mathrm{N} & \mathrm{V} & \mathrm{D} & \mathrm{N} & \mathrm{R} & \mathbf{S} & \mathbf{P} & \mathbf{E} & \mathbf{I} & \mathrm{D} & \mathbf{P} & \mathbf{F} & 60
\end{array} \\
& \text { TGGTATGTGGGGCGCGGTGTGAGACCTATCGGGCGGTTTGGGAAGAGACAGAGTGGAGGT } 240 \\
& \begin{array}{lllllllllllllllllllll}
\text { W } & \mathbf{Y} & \mathbf{V} & \mathbf{G} & \mathbf{R} & \mathbf{G} & \mathbf{V} & \mathbf{R} & \mathbf{P} & \mathbf{I} & \mathbf{G} & \mathbf{R} & \mathbf{F} & \mathrm{G} & \mathrm{K} & \mathrm{R} & \mathrm{Q} & \mathrm{S} & \mathrm{G} & \mathrm{G} & 80
\end{array} \\
& \text { GGTCTGCAGCCAGTGGTCAAATCTTTGGAGATCCTGTTGAACACTCTCAGGAATAAGGAG } 300 \\
& \begin{array}{lllllllllllllllllllll}
G & \mathrm{~L} & \mathrm{Q} & \mathrm{P} & \mathrm{V} & \mathrm{V} & \mathrm{K} & \mathrm{S} & \mathrm{L} & \mathrm{E} & \mathrm{I} & \mathrm{L} & \mathrm{L} & \mathrm{N} & \mathrm{T} & \mathrm{L} & \mathrm{R} & \mathrm{N} & \mathrm{K} & \mathrm{E} & 100
\end{array} \\
& \text { AGCTTGAGGAGTGAGCTGGCGCAGGAGGAGTCAGATTGGTTACCGTGAGATCTGCTACCT } 360 \\
& \begin{array}{lllllllllllllllll}
\mathrm{S} & \mathrm{L} & \mathrm{R} & \mathrm{S} & \mathrm{E} & \mathrm{L} & \mathrm{A} & \mathrm{Q} & \mathrm{E} & \mathrm{E} & \mathrm{S} & \mathrm{D} & \mathrm{W} & \mathrm{L} & \mathrm{P} & * & 115
\end{array} \\
& \text { ACAGCGACCTGCTGCTGTAATATTTAGGTGTATTAGTGTGTATAATTAATCACAGTTTTC } 420 \\
& \text { TCATTCTTTCCCTGGCTGTGTGTACCTCAATATTCATTTCAAATAAACTGACTAGCCAGT } 480 \\
& \text { ССАААААААААААААААААААА } \\
& 502
\end{aligned}
$$

Figure 1. Nucleotide sequence of partial carp C-RFa CDNA, including the poly(A) tail and the deduced amino acid sequence. The numberings of the nucleotide and amino acid sequences are indicated on the sides. The stop codon is represented by an asterisk. The polyadenylation signal site is underlined. 

C. aur
MLPTAITQP---VTKCLIGSRLGTIAFLLLLI 29
C. carp
D. rerio
S. sal
O. keta
o. mosam
C. aur
C. carp
D. rerio
S. sal
o. keta
o. mosam
C. aur
C. carp
D. rerio
S. sal
o. keta
o. mosam

Figure 2. Alignment of deduced carp prepro C-RFa amino acid sequence with other teleost sequences. Prepro C-RFa carp (C. carp), Atlantic salmon (S. sal) (Montefusco-Siegmund et al. 2006), chum salmon (O. keta) (Moriyama et al. 2002), Japanese crucian carp (C. aur) (Fujimoto et al. 1998), tilapia (O. mosam) (Seale et al. 2002) and zebrafish (D. rerio) (Lagerstrom et al. 2005). The asterisks represent conserved residues relative to carp preproC-RFa. The dashed line indicates a gap and the bioactive peptide of 20 amino acid residues is surrounded with a box.

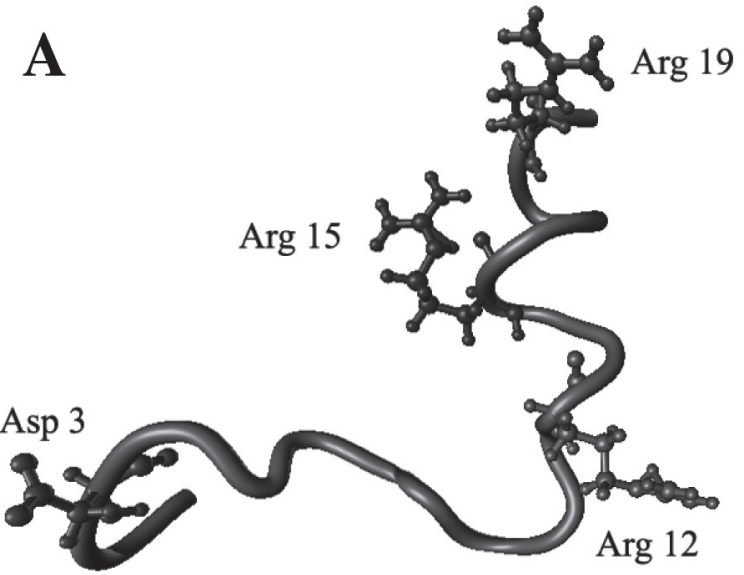

h-PrRP20

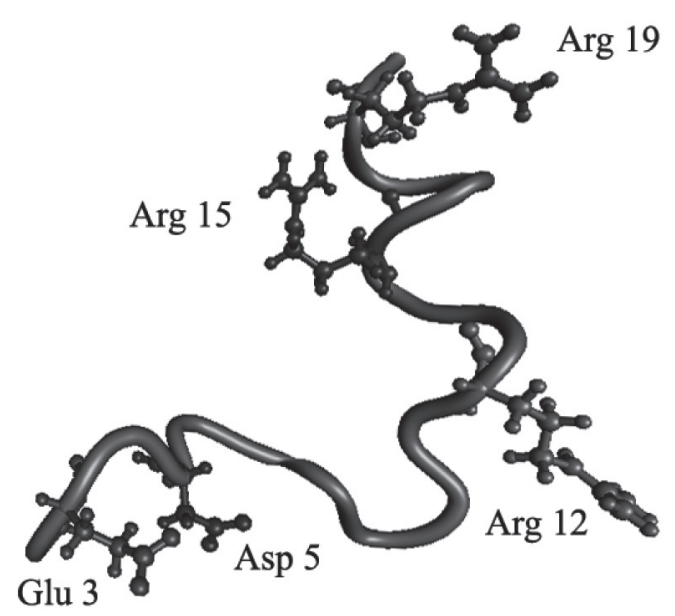

$\mathrm{C}-\mathrm{RFa}$

\section{B h-PIRP20 TPDINPAWYASRGIRPVGRF 20 C-RFa SPEIDPFWYVGRGVRPIGRF 20

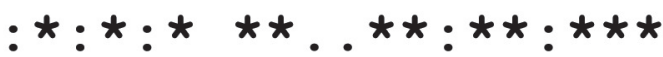

Figure 3. Teleost C-RFa and Human PrRP structure. (A) Charged residues are noted (ball and stick). (B) Amino acid sequence alignment between teleost h-PrRP20 and C-RFa (asterisks indicate identical residues). 

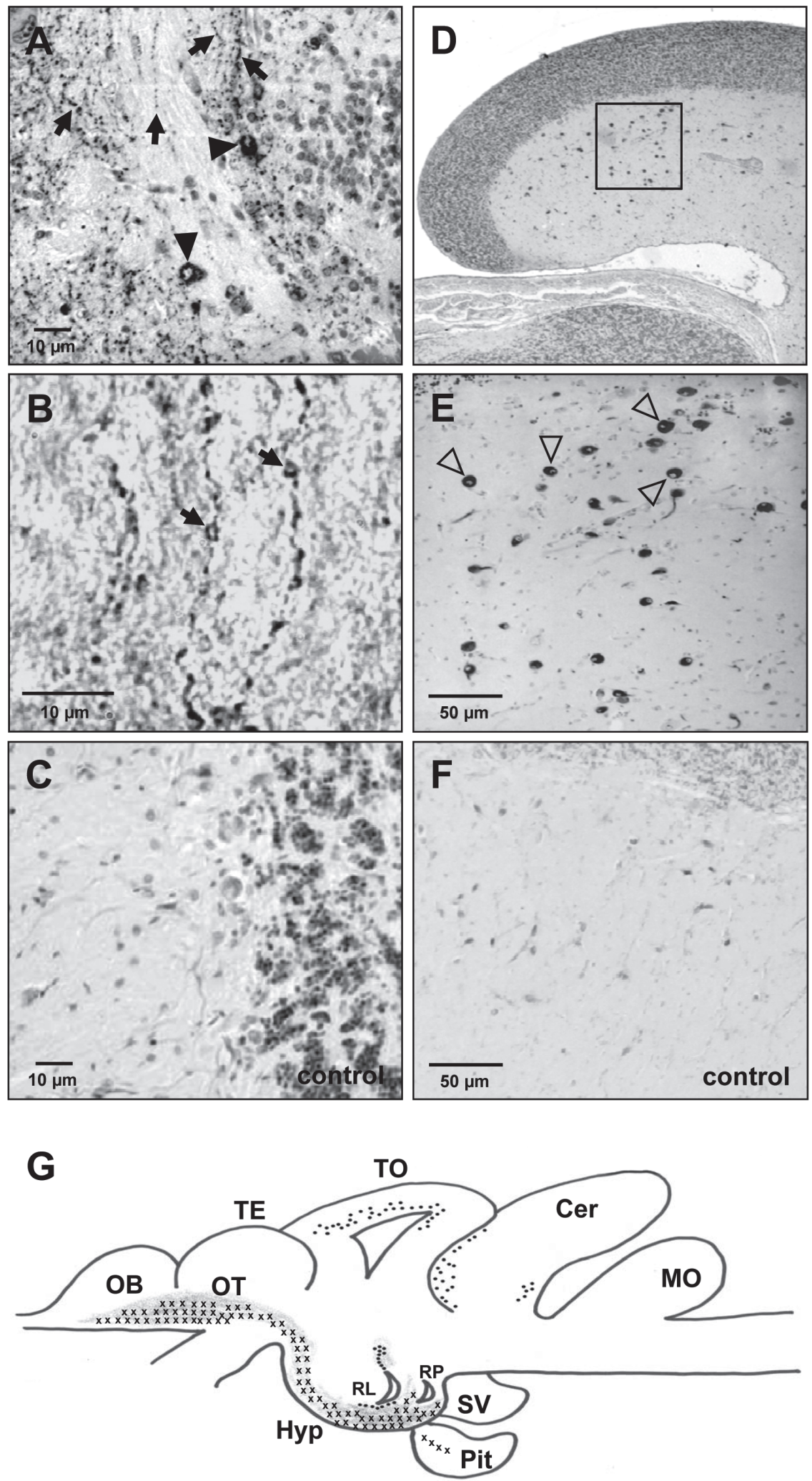

Figure 4. Immunodetection of C-RFa bioactive peptide in sagittal sections of carp brain. A: immunoreaction of C-RFa hypothalamus, numerous immunoreactive fibers (arrow) and a small number of stained cells can be observed (shaded arrowheads). B: immunoreactive signal of C-RFa in herring bodies present in the pituitary stalk (arrows). D: numerous and strongly stained cell bodies were found in the cerebellum. E, amplification of the square in (D), immunoreactive perikarya are shown (unshaded arrowheads). C and $F$, show the control for hypothalamus and cerebellum with an antibody preabsorbed with synthetic C-RFa peptide. G: schematic illustration of a sagittal section of brain showing the C-RFa immunodistribution. Dots indicate cell bodies and crosses indicate fibers. OB, olfactory bulb; OT, olfactory tract; $\mathrm{TE}$, telencephalon; Cer, cerebellun; RL, recessus lateralis; RP, recesus posterior; SV, saccus vasculosum; Pit, pituitary; Hyp, hypothalamus; MO, medulla oblongata; TO, tectum opticum. 
immunoreaction decreased in lactotroph cells, leaving only the nuclear counterstain (Fig. 5A). No change in the prolactin immunodetection was apparent in the mock treated control cells (Fig. 5A). The decrease of PRL immunoreaction in cells was concomitant to the appearance of PRL in the culture medium, as detected by Western blot analyses (Fig. 5B). Our observations suggest that C-RFa stimulates PRL release in vitro.

\section{C-RFa expression during acclimatization}

To evaluate modulation of C-RFa expression during seasonal acclimatization and to map more precisely its cellular distribution in pituitary, immunohistochemistry was performed on successive sections of pituitaries from male adult winter and summer carp. Using the specific antibody against C-RFa (Montefusco-Siegmund et al. 2006), specific immunoreaction was detected in carp pituitary sections (Fig. 6). Similar to the increased expression of various pituitary factors (Figueroa et al. 2005; Figueroa et al. 1994), the signals observed with C-RFa antibodies were much stronger in pituitaries from summer carp, especially in the proximal pars distalis and pars intermedia (Fig. 6, C and D). This became evident with the semi-quantitative analyses obtained upon digitalization of the immuno signals (Fig. 6 E).

In order to analyze the C-RFa expression from summer and winter carp, the level of hypothalamic mRNA of the peptide was determinate by real time PCR. The highest level of mRNA expression of C-RFa was seen in summer carp, reaching a significant difference in comparison to the constitutive expression of mRNA peptide in the hypothalamus of winter carp (Fig. 7).

\section{DISCUSSION}

In the present study, we described the cloning of prepro C-RFa cDNA from carp (Cyprinus carpio). The deduced preprohormone precursor present $95 \%$ and $89 \%$ similarity to crucian carp and zebrafish respectively, while the mature peptide presented $100 \%$ identity to all fish bioactive C-RFa (Kwong and Woo 2008; Montefusco-Siegmund et al. 2006; Moriyama et al. 2002; Seale et al. 2002). The conservation over $400 \mathrm{MYA}$ in sequence and structure of teleost C-RFa to mammalian PrRP (60\%) strongly suggests a pivotal role for this hypothalamic peptide in vertebrates.

In carp, as in other preproC-RFas, a singular and amidated bioactive peptide seems to be produced by a unique proteolytic cleavage site (Hinuma et al. 1998; Satake et al. 1999). In mammals, an additional longer form of 31 amino acids was described, the biological importance of which is unclear (Hinuma et al. 1998). However, the canonical C-terminal amidation motif present in the RFamide peptide family constitutes a key feature, since lack of this motif dramatically reduces biological activity in mammals and teleost (Roland et al. 1999; Satake et al. 1999).

Using the human PrRP20 (h-PrRP20) coordinates, we obtained a structural model of teleosteal C-RFa, which showed a rigid $\alpha$-helical structure in the C-terminal end and flexible N-terminal end. Analysis of the structural model of the C-RFa peptide (Fig. 3A) predicts a conformation similar to that of h-PrRP20. Both structures are characterized by a similar C-terminal, apparently amphipatic helix formed by the polar arginine side chains at positions 12, 15 and 19 and the hydrophobic Val10, Val14, and Phe20. The conserved arginine residues at positions 15 and 19 of the mammalian PrRP20 are critical for its binding to the prolactin releasing hormone receptor, GPR10 (O'Dowd et al. 1995), as their substitution with either lysine or citrulline substantially reduces affinity of the h-PrRP31 peptide (Roland et al. 1999), supporting the critical structural significance of this region (Roland et al. 1999). Structural similarity was also observed between h-PrRP20 and neuropeptide Y, NPY (D'Ursi et al. 2002). Arg19 in C-RFa corresponds to Arg35 in NPY, which has been reported to be

\section{A}

$t_{0}$

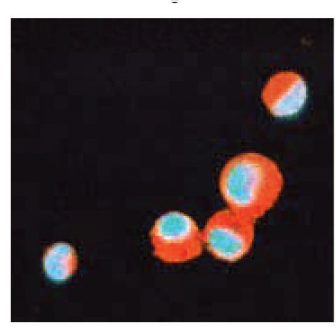

B
$5 \mathrm{~min}$

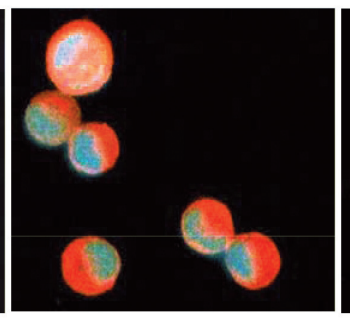

$10 \mathrm{~min}$

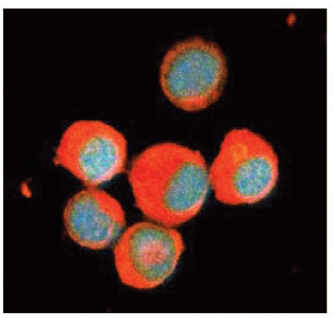

$30 \mathrm{~min}$

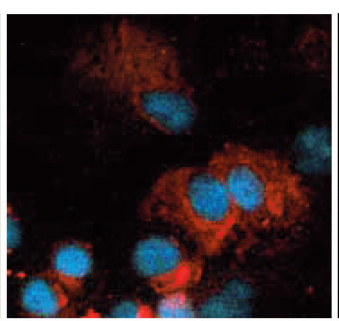

mock (30 $\mathrm{min})$

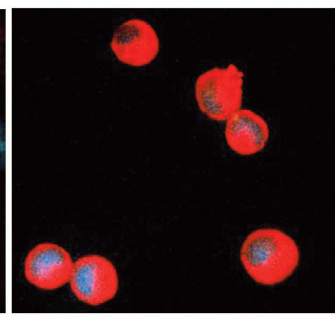

Time (min)

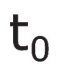

5

10

30
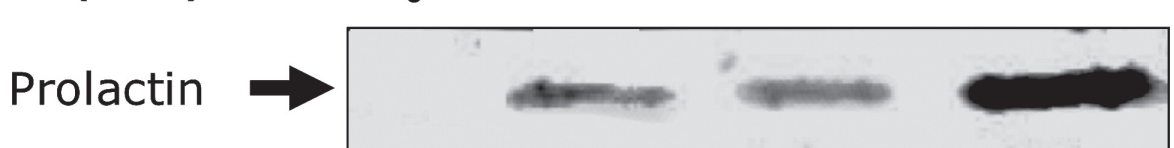

Figure 5. C-RFa stimulates PRL release from primary culture of trout pituitary cells. (A) After C-RFa treatment, the decrease of immunoreaction for PRL (red) in lactrophs after 30 min was accompanied by an increase of PRL immunodetection via Western blot analyses in the cell culture medium (B). Nuclei were stained by DAPI or 4',6-diamidino-2-phenylindole (blue). Mock, vehicle of PrRP. Results of one of two independent experiments are shown. 
Winter
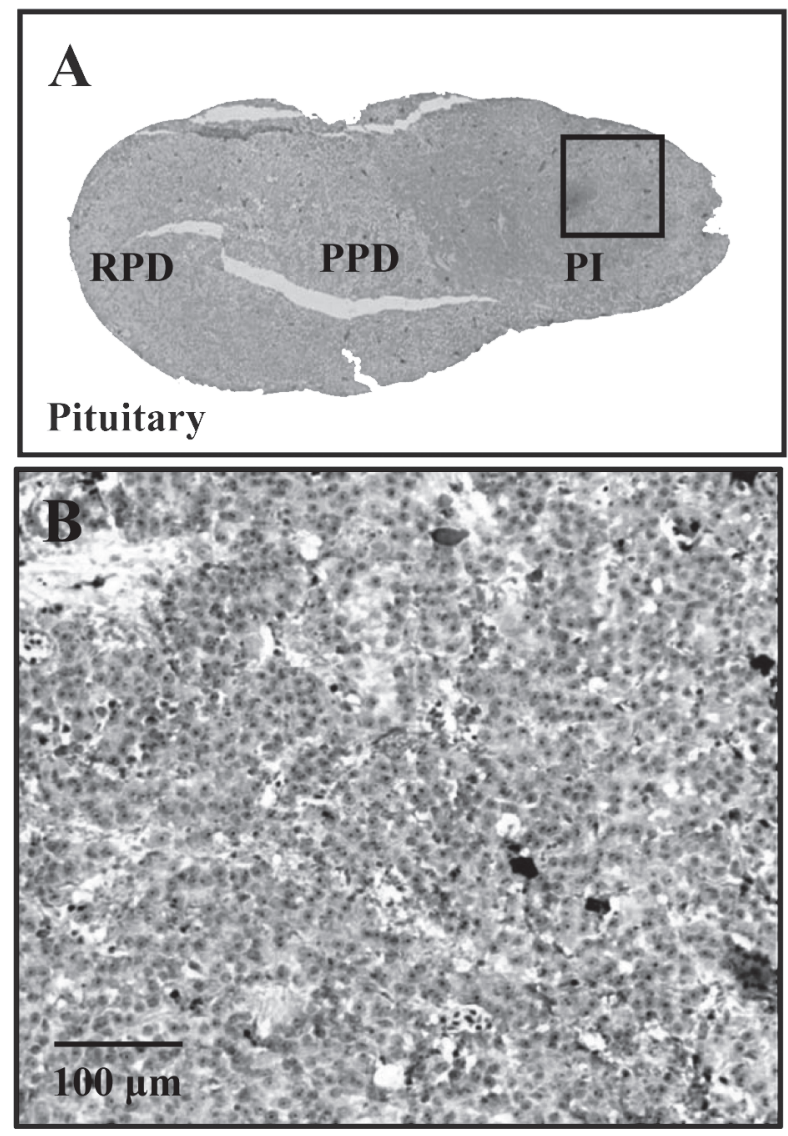

Summer
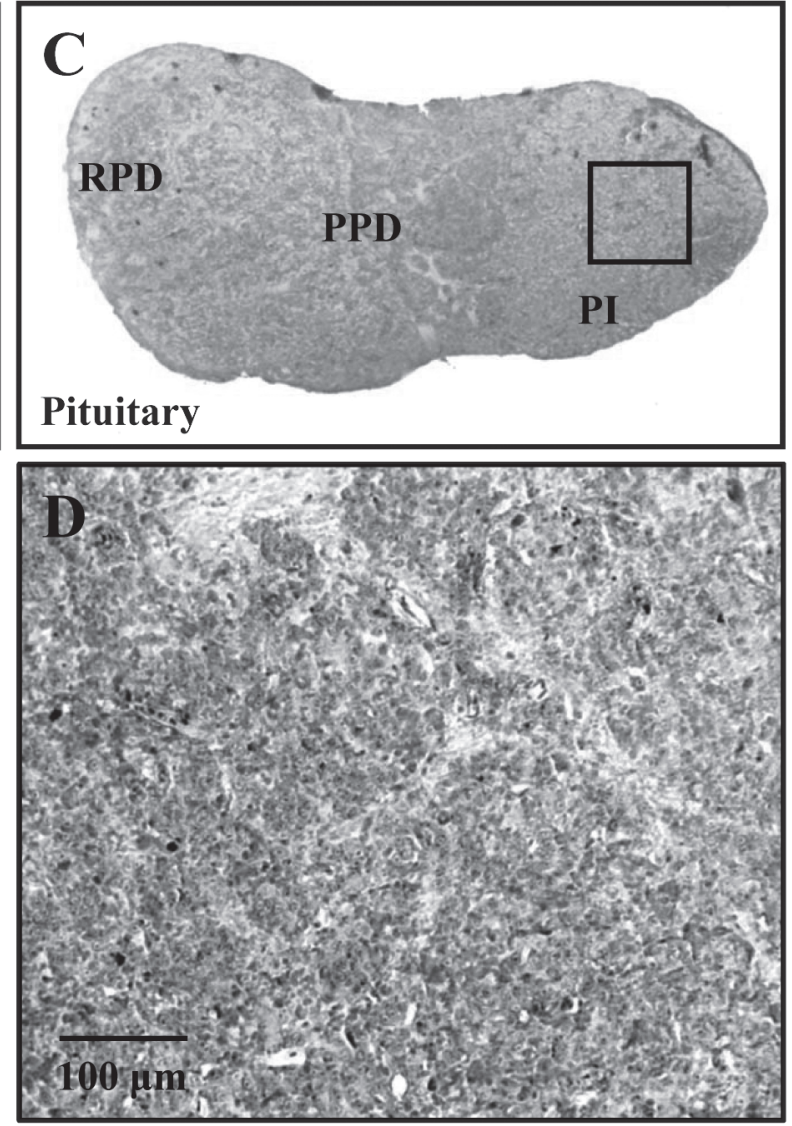

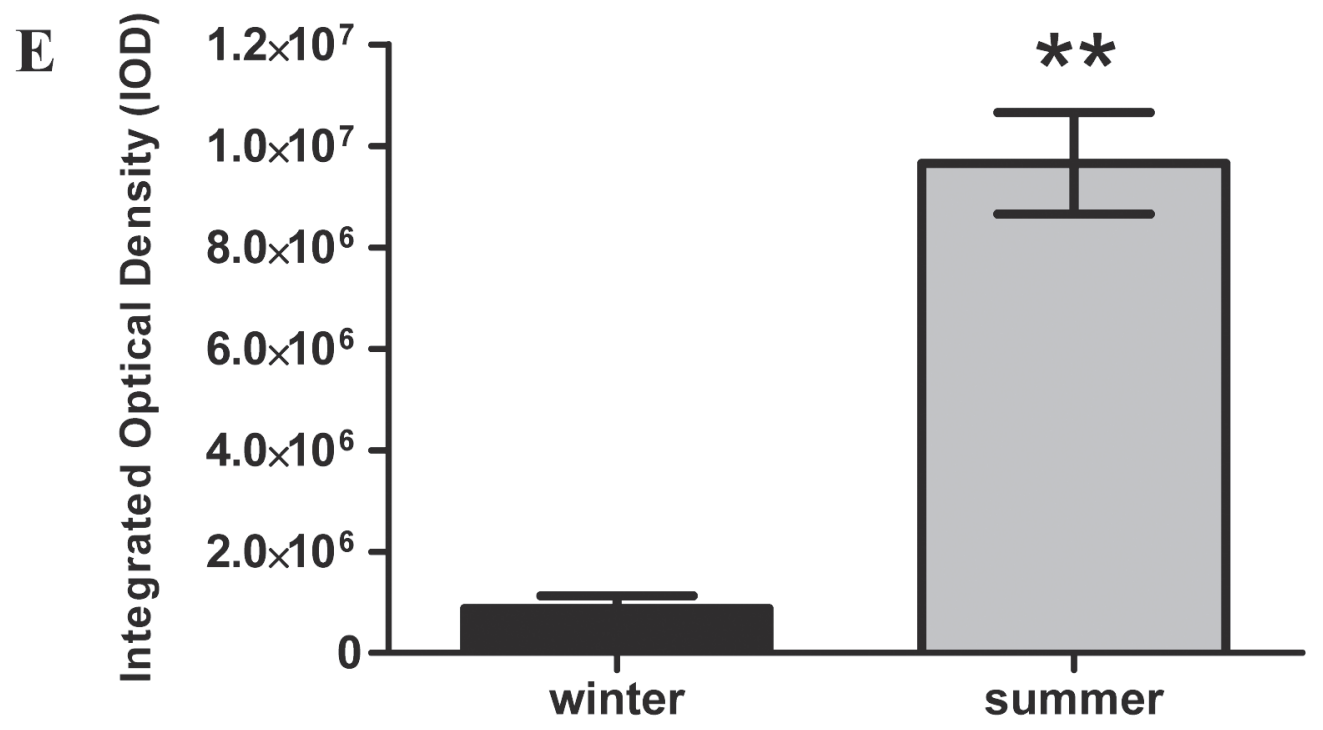

Figure 6. C-RFa protein levels are significantly increased in pituitary of summer relative to winter acclimatized carp. Immunoreaction of C-RFa in pituitary of winter (A) and summer (C) located in the pars intermedia (PI). B and D, amplification of the square in A and C, showing immunoreactive signal in PI of carp pituitary. E: Graph represent differences of signals quantified in digitalized pictures of four male carp individuals $(n=4)$ from each season. Columns represent mean integrated optical density (IOD) with standard deviation indicated by bars. ${ }^{* *}, P<0.0004$ vs. winter carp. 
crucial for NPY activity since its single replacement by Ala leads to a complete loss of affinity for all cloned NPY receptor subtypes (Cabrele and Beck-Sickinger 2000). In the N-terminal region of the proposed model for the C-RFa peptide, a tendency to form a $\beta$-turn structure is predicted which includes two highly conserved proline residues (Pro2 and Pro6, Fig. 3). This characteristic is shared with hPrRP, where it confers more flexibility to this region. Finally, the common threedimensional arrangement in C-RFa, hPrPR20 and NPY peptide suggest a common and conserved mechanism for receptorrecognition (Bader et al. 2001; D'Ursi et al. 2002). In the case of C-RFa, the C-terminal amphiphilic alpha-helix could allow interaction with hydrophobic and hydrophilic components of the cell membrane, inducing the bioactive conformation required for receptor binding ( $D^{\prime} U_{r s i}$ et al. 2002).

Similar to others teleosts, we observed a wide distribution of the C-RFa peptide in several brain regions, including olfactory tract, hypothalamus and cerebellum. This suggests, similar to mammalian PrRP, that this peptide might be involved in regulation of multiple physiological events in fish (Maruyama et al. 1999). In carp, highly C-RFa immunoreactive cell bodies are mainly present in the cerebellum (Fig. 4), a localization that is not observed in rat, rainbow trout or goldfish (Moriyama et al. 2002; Roland et al. 1999; Wang et al. 2000). Even though these cells could be involved in cerebellar functions, such as cognitive and emotional processes (Rodriguez et al. 2005), a participation of C-RFa in cerebellar growth control cannot be ruled out, since h-PrRP has been shown to regulate growth in PC12 cells (Samson and Taylor 2006). In mammals and birds, postnatal neurogenesis appears to be kept at low rates (Zupanc 1999; Zupanc and Horschke 1995) while in teleosts, specifically the cerebellum and tectum opticum regions are known as highly prolific zones in the central nervous system (Zupanc and Horschke 1995). The extensive immunoreaction to C-RFa of cells in the cerebellum

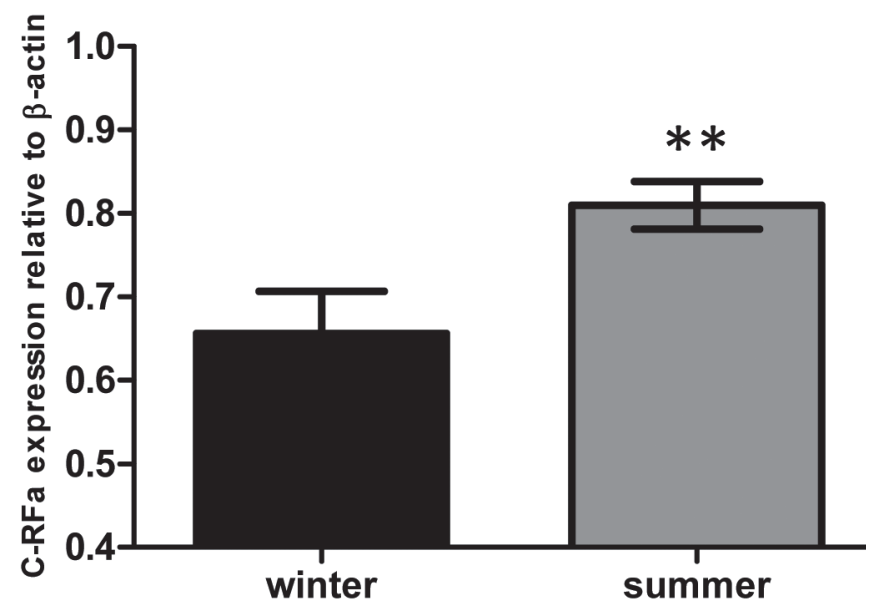

Figure 7. C-RFa transcript level analyzed by real-time RT-PCR in pituitary of acclimatized carp. Expression was determined by quantitative real time PCR and plotted relative to the expression of $\beta$-actin. The columns represent the constitutive expression of three winter and summer acclimatized carp. Quantitative RT-PCR reactions were performed in triplicate. ${ }^{* *}, P<0.03$ vs. winter carp. of carp brain is highly suggestive of a function in cell proliferation processes for C-RFa in this area.

The hypophysiotropic activity of the C-RFa peptide in vitro from the pituitary gland of rainbow trout was shown in a perifusion system, indicating that C-RFa is a specific PRL releasing factor in teleost fish (Moriyama et al. 2002). Although $1 \mathrm{uM}$ is described as the optimal concentration for peptide activity in trout, we could induce PRL secretion with $10 \mathrm{nM}$ C-RFa (Moriyama et al. 2002). PRL signal disappeared from inside the cells and was detected in the medium after $30 \mathrm{~min}$. Since we observed only lactotrophs in the 24-hour primary culture, our results indicate that the PRL releasing activity of the peptide could be achieved through direct interaction with PRL cells, probably through the interaction with its receptor, which was cloned from tilapia and the receptor binding confirmed by intracellular calcium mobilization assay in $\mathrm{CHO}$ cells, expressing the recombinant receptor (Watanabe and Kaneko 2010). Spontaneous PRL release was not observed in the primary pituitary cell culture. This is in agreement with the observation of pituitary explants, which did not release PRL in the untreated culture (Flores et al. 2007). Mainly lactotrophs were identified by immunofluorescence in the primary cell culture, suggesting that the missing inhibitory effect of hypothalamic dopamine led predominantly to proliferation of lactotrophs (Asa et al. 1999; Iaccarino et al. 2002).

Finally, the fact that the fibers are clearly immunopositive for C-RFa in the pituitary stalk of carp supports the notion that the peptide is transported by axons from the hypothalamus and delivered into the pituitary, where C-RFa might interact with the PRL cells promoting PRL release. Interestingly, the level of expression of the C-RFa peptide increased in the pituitary gland from summer carp by immunohistoquemistry, with a strong immunoreactive signal located in the PPD and neurohypophysis (Fig. 6). This localization of carp C-RFa could be related to the expression of the PrRP receptor in tilapia, which was also detected in (RPD) and neurohypophysis in tilapia pituitary. In addition, it is probable that not only PRL production increases in summer carp, as described for this teleost (Figueroa et al. 1994), but also the production of its hypothalamic releasing peptide, as described by real time RTPCR in this study (Fig. 7). In conclusion, modulation of PRL expression is a main event for seasonal acclimatization in carp and the increase of the C-RFa expression suggests participation of this hypothalamic factor in the mechanism of modulation in PRL expression in carp.

\section{ACKNOWLEDGMENTS}

This work was supported in part by grants: Fondecyt 1070724; Fondecyt 1040073 and DID-UACh 2003-13 .

\section{REFERENCES}

ASA SL, KELLY MA, GRANDY DK, AND LOW MJ (1999) Pituitary lactotroph adenomas develop after prolonged lactotroph hyperplasia in dopamine D2 receptor-deficient mice. Endocrinology 140:5348-55.

BADER R, BETTIO A, BECK-SICKINGER AG, AND ZERBE O (2001) Structure and dynamics of micelle-bound neuropeptide $Y$ : comparison with unligated NPY and implications for receptor selection. J Mol Biol 305:307-29.

BARRY TP, AND GRAU EG (1986) Estradiol-17 beta and thyrotropinreleasing hormone stimulate prolactin release from the pituitary gland of a teleost fish in vitro. Gen Comp Endocrinol 62:306-14. 
CABRELE C, AND BECK-SICKINGER AG (2000) Molecular characterization of the ligand-receptor interaction of the neuropeptide $Y$ family. J Pept Sci 6:97-122.

CHANG JP, AND JOBIN RM (1994) Teleost pituitary cells: isolation, culture and use. in Biochemistry and Molecular Biology of Fishes, edited by Hochachka PW, and Mommsen TP.. Amsterdam: Elsevier:p. 205-213.

D'URSI AM, ALBRIZIO S, DI FENZA A, CRESCENZI O, CAROTENUTO A, PICONE D, NOVELLINO E, AND ROVERO P (2002) Structural studies on Hgr3 orphan receptor ligand prolactin-releasing peptide. J Med Chem 45:5483-91.

FIGUEROA J, MARTIN RS, FLORES C, GROTHUSEN H, AND KAUSEL G (2005) Seasonal modulation of growth hormone mRNA and protein levels in carp pituitary: evidence for two expressed genes. J Comp Physiol B 175:185-92.

FIGUEROA J, MOLINA A, ALVAREZ M, VILLANUEVA J, REYES A, LEON G, AND KRAUSKOPF M (1994) Prolactin gene expression and changes of prolactin pituitary level during the seasonal acclimatization of the carp. Comp Biochem Physiol Biochem Mol Biol 108:551-60.

FLORES CM, MUÑ OZ D, SOTO M, KAUSEL G, ROMERO A, AND FIGUEROA J (2007) Copeptin, derived from isotocin precursor, is a probable prolactin releasing factor in carp. Gen Comp Endocrinol 150:343-54.

FREDRIKSSON R, LAGERSTROM MC, LUNDIN LG, AND SCHIOTH HB (2003) The G-protein-coupled receptors in the human genome form five main families. Phylogenetic analysis, paralogon groups, and fingerprints. Mol Pharmacol 63:1256-72.

FUJIMOTO $M$, TAKESHITA $K$, WANG $X$, TAKABATAKE I, FUJISAWA Y, TERANISHI H, OHTANI M, MUNEOKA Y, AND OHTA S (1998) Isolation and characterization of a novel bioactive peptide, Carassius RFamide (C-RFa), from the brain of the Japanese crucian carp. Biochem Biophys Res Commun 242:436-40.

GRAU EG, NISHIOKA RS, AND BERN HA (1982) Effects of somatostatin and urotensin II on tilapia pituitary prolactin release and interactions between somatostatin, osmotic pressure $\mathrm{Ca}++$, and adenosine $3^{\prime}, 5^{\prime}$-monophosphate in prolactin release in vitro. Endocrinology 110:910-5.

HELMS LM, GRAU EG, AND BORSKI RJ (1991) Effects of osmotic pressure and somatostatin on the cAMP messenger system of the osmosensitive prolactin cell of a teleost fish, the tilapia (Oreochromis mossambicus). Gen Comp Endocrinol 83:111-7.

HINUMA S, HABATA Y, FUJII R, KAWAMATA Y, HOSOYA M, FUKUSUMI S, KITADA C, MASUO Y, ASANO T, MATSUMOTO H, SEKIGUCHI M, KUROKAWA T, NISHIMURA O, ONDA H, AND FUJINO M (1998) A prolactin-releasing peptide in the brain. Nature 393:272-6.

HUMPHREY W, DALKE A, AND SCHULTEN K (1996) VMD: visual molecular dynamics. J Mol Graph 14:33-8, 27-8.

IACCARINO C, SAMAD TA, MATHIS C, KERCRET H, PICETTI R, AND BORRELLI E (2002) Control of lactotrop proliferation by dopamine: essential role of signaling through D2 receptors and ERKs. Proc Natl Acad Sci U S A 99:14530-5.

KWONG AK, AND WOO NY (2008) Prolactin-releasing peptide, a possible modulator of prolactin in the euryhaline silver sea bream (Sparus sarba): A molecular study. Gen Comp Endocrinol 158:154-60.

LAGERSTROM MC, FREDRIKSSON R, BJARNADOTTIR TK, FRIDMANIS D, HOLMQUIST T, ANDERSSON J, YAN YL, RAUDSEPP T, ZOOROB R, KUKKONEN JP, LUNDIN LG, KLOVINS J, CHOWDHARY BP, POSTLETHWAIT JH, AND SCHIOTH HB (2005) Origin of the prolactinreleasing hormone (PRLH) receptors: evidence of coevolution between PRLH and a redundant neuropeptide $\mathrm{Y}$ receptor during vertebrate evolution. Genomics 85:688-703.

MANZON LA (2002) The role of prolactin in fish osmoregulation: a review. Gen Comp Endocrinol 125:291-310.

MARCHESE A, HEIBER M, NGUYEN T, HENG HH, SALDIVIA VR, CHENG R, MURPHY PM, TSUI LC, SHI X, GREGOR P, AND ET AL. (1995) Cloning and chromosomal mapping of three novel genes, GPR9, GPR10, and GPR14, encoding receptors related to interleukin 8, neuropeptide $Y$, and somatostatin receptors. Genomics 29:335-44.

MARTI-RENOM MA, STUART AC, FISER A, SANCHEZ R, MELO F, AND SALI A (2000) Comparative protein structure modeling of genes and genomes. Annu Rev Biophys Biomol Struct 29:291-325.

MARTYNIUK CI, AWAD R, HURLEY R, FINGER TE, AND TRUDEAU VL (2007) Glutamic acid decarboxylase 65, 67, and GABA-transaminase mRNA expression and total enzyme activity in the goldfish (Carassius auratus) brain. Brain Res 1147:154-66.

MARUYAMA M, MATSUMOTO H, FUJIWARA K, KITADA C, HINUMA S, ONDA H, FUJINO M, AND INOUE K (1999) Immunocytochemical localization of prolactin-releasing peptide in the rat brain. Endocrinology 140:2326-33.

MONTEFUSCO-SIEGMUND RA, ROMERO A, KAUSEL G, MULLER M, FUJIMOTO M, AND FIGUEROA J (2006) Cloning of the prepro C-RFa gene and brain localization of the active peptide in Salmo salar. Cell Tissue Res.

MORIYAMA S, ITO T, TAKAHASHI A, AMANO M, SOWER SA, HIRANO T, YAMAMORI K, AND KAWAUCHI H (2002) A homolog of mammalian PRL-releasing peptide (fish arginyl-phenylalanyl-amide peptide) is a major hypothalamic peptide of PRL release in teleost fish. Endocrinology 143:2071-9.

O'DOWD BF, SCHEIDELER MA, NGUYEN T, CHENG R, RASMUSSEN JS, MARCHESE A, ZASTAWNY R, HENG HH, TSUI LC, SHI X, AND ET AL. (1995) The cloning and chromosomal mapping of two novel human opioid-somatostatin-like receptor genes, GPR7 and GPR8, expressed in discrete areas of the brain. Genomics 28:84-91.

PFAFFL MW (2001) A new mathematical model for relative quantification in real-time RT-PCR. Nucleic Acids Res 29:e45.

RODRÍGUEZ F, DURAN E, GÓMEZ A, OCANA FM, ÁLVAREZ E, JIMÉNEZ-MOYA F, BROGLIO C, AND SALAS C (2005) Cognitive and emotional functions of the teleost fish cerebellum. Brain Res Bull 66:365-70.

ROLAND BL, SUTTON SW, WILSON SJ, LUO L, PYATI J, HUVAR R, ERLANDER MG, AND LOVENBERG TW (1999) Anatomical distribution of prolactin-releasing peptide and its receptor suggests additional functions in the central nervous system and periphery. Endocrinology 140:5736-45.

SAMBROOK J, FRITSCH EF, AND MANIATIS T (1989) Molecular Cloning: A Laboratory Manual.

SAMSON WK, AND TAYLOR MM (2006) Prolactin releasing peptide (PrRP): An endogenous regulator of cell growth. Peptides.

SATAKE H, MINAKATA H, WANG X, AND FUJiMOTO M (1999) Characterization of a cDNA encoding a precursor of Carassius RFamide, structurally related to a mammalian prolactin-releasing peptide. FEBS Lett 446:247-50.

SEALE AP, ITOH T, MORIYAMA S, TAKAHASHI A, KAWAUCHI $\mathrm{H}$, SAKAMOTO T, FUJIMOTO M, RILEY LG, HIRANO T, AND GRAU EG (2002) Isolation and characterization of a homologue of mammalian prolactin-releasing peptide from the tilapia brain and its effect on prolactin release from the tilapia pituitary. Gen Comp Endocrinol 125:328-39.

WANG X, MORISHITA F, MATSUSHIMA O, AND FUJIMOTO M (2000b) Immunohistochemical Localization of C-RFamide, a FMRF-related Peptide, in the Brain of the Goldfish, Carassius auratus. Zoolog Sci 17:1067-74.

WATANABE S, AND KANEKO T (2010) Prolactin-releasing peptide receptor expressed in the pituitary in Mozambique tilapia Oreochromis mossambicus: An aspect of prolactin regulatory mechanisms. Gen Comp Endocrinol.

WEBER GM, AND GRAU EG (1999) Changes in serum concentrations and pituitary content of the two prolactins and growth hormone during the reproductive cycle in female tilapia, Oreochromis mossambicus, compared with changes during fasting. Comp Biochem Physiol C Pharmacol Toxicol Endocrinol 124:323-35.

WEBER GM, POWELL JF, PARK M, FISCHER WH, CRAIG AG, RIVIER JE, NANAKORN U, PARHAR IS, NGAMVONGCHON S, GRAU EG, AND SHERWOOD NM (1997) Evidence that gonadotropin-releasing hormone $(\mathrm{GnRH})$ functions as a prolactin-releasing factor in a teleost fish (Oreochromis mossambicus) and primary structures for three native GnRH molecules. J Endocrinol 155:121-32.

WELCH SK, O'HARA BF, KILDUFF TS, AND HELLER HC (1995) Sequence and tissue distribution of a candidate G-coupled receptor cloned from rat hypothalamus. Biochem Biophys Res Commun 209:606-13.

YADA T, AND AZUMA T (2002) Hypophysectomy depresses immune functions in rainbow trout. Comp Biochem Physiol C Toxicol Pharmacol 131:93-100.

YADA T, UCHIDA K, KAJIMURA S, AZUMA T, HIRANO T, AND GRAU EG (2002) Immunomodulatory effects of prolactin and growth hormone in the tilapia, Oreochromis mossambicus. J Endocrinol 173:483-92.

ZUPANC GK (1999) Neurogenesis, cell death and regeneration in the adult gymnotiform brain. J Exp Biol 202:1435-46.

ZUPANC GK, AND HORSCHKE I (1995) Proliferation zones in the brain of adult gymnotiform fish: a quantitative mapping study. J Comp Neurol 353:213-33. 
